\title{
Is replacement theology anti-Semitic?
}

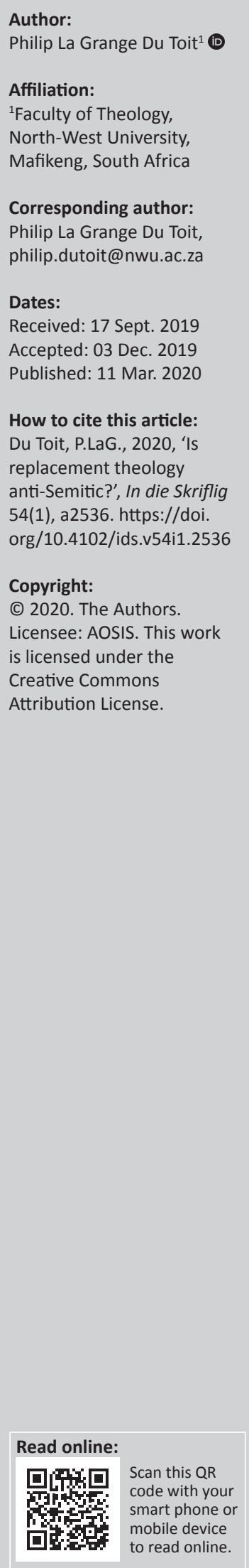

In this article, the question is asked whether replacement theology is anti-Semitic - a critique that is often advanced in discourse on replacement theology. In answering this question, the definitions of antisemitism and replacement theology are revisited and the question whether replacement forms part of the hermeneutic of the New Testament writers is addressed. Subsequently, the core of what is actually replaced is determined, as well as the hermeneutic principles that distinguish replacement and anti-replacement approaches. It is found that the notion of replacement is inevitable, in the way in which writers of the New Testament convey concepts such as fulfilment, messianism, eschatology and newness. It is argued that at heart, the criteria of identity and covenant membership are replaced in the new eschatological epoch in Christ, which exclude race, biological descent or ethnicity and thus cannot be anti-Semitic.

Keywords: supersessionism; replacement theology; antisemitism; anti-Judaism; eschatology; identity.

\section{Introduction}

In the preface of an edited publication that appeared recently, titled Israelism and the place of Christ: christocentric interpretation of biblical prophecy, the editor, Steven Paas (2018:10), writes that the authors in this work 'categorically denounce the ideas of antisemitism and replacement theology, which in the course of the centuries have damaged the relationship between Jews and Christians'. In a similar vein, he (Paas 2018) writes:

Some Christians and Jews think that those who defend the classical Christocentric view of Scripture - that the salvific meaning of Old Testament Israel has been completely effected and absorbed by Christ - are adherents of a replacement theology and of certain forms of antisemitism or hatred of Jews. (p. 28)

Paas (2018:28) distantiates himself from 'the idea of replacing Israel by the Church' and antisemitism. He also states that 'adherence to the - now disgraced - replacement theory can go hand in hand with anti-Jewish sentiments' (Paas 2018:36). From these quotes it can with reasonable certainty be concluded that Paas identifies the idea of the so-called replacement theology or supersessionism with antisemitism.

Of course, the proposed connection between antisemitism and replacement theology is not new in New Testament scholarship. Although Gager (2000) does not draw such linear lines between antisemitism and the idea of replacement, he writes:

I would not claim that Paul, or even Christianity as a whole, is responsible for modern anti-Semitism. But Paul in the traditional reading has been an important part of that story. (p. 18)

He elsewhere describes the traditional reading of Paul as involving 'the rejection-replacement view' (Gager 2000:5, 10, 14-15). Similarly, Donaldson (2009:8) argues that 'while "supersessionism" has taken its place in the discussion alongside "anti-Judaism" and "antisemitism," it does not function simply as a synonym for either of these terms', but adds that 'there is a considerable measure of overlap among all three' and that 'each of the terms tends to highlight different aspects of the larger phenomenon'.

Another tendency that often goes hand in hand with the way in which antisemitism is understood, is the notion that anti-Judaism is seen as a kind of precursor for antisemitism (e.g. Byford 2006; Gager 1983; Hoet 2001:187-188; Langmuir 1971; Nichols 1993:314). The reasoning behind this tendency is normally that, historically, a negative view of Judaism has often led to antisemitism. This is probably one of the reasons why Catholic education in which anti-Judaism was seen as an integral part of the defence of the Christian faith, was changed after the Second Vatican Council between 1962 and 1965 (Carrol 2002:40). Critics of replacement theology often perceive a continuum between replacement theology, anti-Judaism and antisemitism as if there exists an unbroken chain or at least a close relationship between these concepts. 
The primary aim of this article is to determine whether replacement theology or supersessionism is inherently antiSemitic or inevitably gives rise to antisemitism. In order to answer this basic question, the following four questions will be discussed before the main question will be addressed: (1) What exactly is meant by the concepts antisemitism and replacement theology? (2) Is replacement in some form inherently part of the hermeneutic of the New Testament writers, especially Paul? (3) If so, what exactly is replaced according to Paul? (4) What hermeneutic principles distinguish replacement and anti-replacement approaches? After these questions are addressed, the fifth and main question, namely whether replacement theology is inherently anti-Semitic, will be addressed.

\section{What exactly is meant by the concepts antisemitism and replacement theology?}

While 'anti-Judaism' usually refers to opposition to the religious convictions or customs of the Jews, 'antisemitism' is normally understood as prejudice or hatred against Jewish people as a race ${ }^{1}$ or ethnic ${ }^{2}$ entity (Bartkowski 2007:152; Beller 2007:1-2; Donaldson 2009:8; Langmuir 1971; Murrell 1994), which could involve perceptions about their economic standing and political power (Bartkowski 2007:152). The study of antisemitism has especially been dominated by the role it played in the holocaust (Beller 2007:2; cf. Bartkowski 2007:152), which is often used as an example of the consequence of antisemitism in practice.

In respect of the concept of replacement theology or supersessionism, definitions vary. N.T. Wright (2013:806-810) distinguishes between three versions of supersessionism: (1) 'hard' supersessionism; (2) 'sweeping' supersessionism; and (3) 'Jewish' supersessionism. Firstly, in regard to 'hard' supersessionism, Wright argues that some early Christian writers seem to teach that, as a consequence of the gospel, Israel, as God's people, was cast off and has been replaced by gentile believers (cf. Barnabas 4.7; 9.4; 14.1-5). In this scheme, the church consists of people of gentile origin only. In recent times, this is more of a hypothetical position than being an argued position. However, this is the kind of (hypothetical) position against which scholars such as R. Kendall Soulen (1996:1) and Terence L. Donaldson (2009:7) argue when they label replacement theology as a 'theology of displacement'. Donaldson (2009) becomes more specific when he argues that 'supersessionism':

1.Langmuir (1990:311-314) argues that the belief that large human groups are sharply differentiated according to hereditary biological traits is a myth. In othe words, 'racism' is a social construct and cannot as such be the explanation of the myth or of the phenomenon of antisemitism. He describes antisemitism in terms of 'socially significant chimerical hostility' (Langmuir 1990:341).

2.Ethnicity is normally considered to be a broader concept than race. In antiquity, an ethnos denoted a common name, a myth of common ancestry, a shared history, common culture, common customs, a link with a homeland and a sense of communal solidarity (Mason \& Esler 2017:502). Much of these connotations have been retained in recent definitions of ethnicity. Although the concept of ethnicity in been retained in recent definitions of ethnicity. Although the concept of ethnicity in sociological definitions normally includes ties of kin' that 'arise largely from biological inheritance' (Stone \& Piya 2007:1457), it became an accepted theory that 'racial differences are biologically insignificant and that ethnicity must be considered quite apart from its assumed associations with race' (Lemert 2006:174). Yet, th concept of ethnicity includes connotations about 'customs, religions, cuisines and other cultural practices' (Lemert 2006:174) as well as connotations about a nation's traditions and institutions (Stone \& Piya 2007:1457).

\begin{abstract}
$\ldots[D]$ escribes a situation where one entity, by virtue of its supposed superiority, comes to occupy a position that previously belonged to another, the displaced group becoming outmoded or obsolete in the process. The term thus properly applies to a completed process of replacement. For this reason, it is most immediately applicable in a situation where 'Christianity' and 'Judaism' are-or are perceived to be-more or less separate entities and the church is recognizably non-Jewish. (p. 9)
\end{abstract}

Secondly, Wright (2013:807) identifies 'sweeping' supersessionism with post-Barthian or postliberal theology. This kind of theology envisions an 'invasion' into the world, which 'rendered redundant anything and everything that had gone before - particularly anything that looked like "religion"', including 'covenantal religion'. This approach denies any historical continuity with the past. It is not that Israel has turned into the church; it is rather that Israel and everything else prior to apocalyptic announcement of the gospel 'has been swept aside by the fresh revelation' (Wright 2013:807; cf. Käsemann 1980:302; Martyn 1997). In the third variety, Wright (2013:809) argues for a 'Jewish' supersessionism in which prophecy is fulfilled and the covenant is renewed. A new people are called who are 'emphatically in continuity with Abraham, Isaac and Jacob'. Torah is kept in 'the new way', which God 'had always envisaged'. Wright points out that this is the kind of supersessionism that is found in the Qumran literature (cf. Levenson 1993:x). Many of the smaller sects would see themselves in this sense as 'the true Israel' (Wright 2013:809), which amounts to 'a characteristically Jewish note of fulfilment' (Wright 2013:810, [emphasis original]). Wright argues that 'Paul's revision of the Jewish view of election was more or less of the same type as what we find in Qumran' (Wright 2013:810). This is also the kind of supersessionsism that Wright himself seems to advocate.

Soulen $(1996: 28-33 ; 2013: 284)$ argues for three different forms of replacement theology, which are not necessarily mutually exclusive. He distinguishes between 'punitive', 'economic' and 'structural' supersessionism: Firstly, in so-called 'punitive' supersession, 'God abrogates God's covenant with Israel (which is already in principle outmoded) on account of Israel's rejection of Christ and the gospel' (Soulen 1996:30). Secondly, in 'economic' supersessionism, Soulen (1996) argues that:

[E]verything that characterized the economy of salvation in its Israelite form becomes obsolete and is replaced by its ecclesial equivalent. The written law of Moses is replaced by the spiritual law of Christ, circumcision by baptism, natural descent by faith as criterion of membership in the people of God, and so forth. (p. 29)

In the third place, the so-called 'structural' supersessionism 'unifies the Christian canon in a manner that renders the Hebrew Scriptures largely indecisive for shaping conclusions about how God's purposes engage creation in universal and enduring ways'. In respect of Wright's third version of supersessionism (see above), the idea of a unified canon seems to be present, but not the idea that the Old Testament is indecisive about God's ultimate purposes. Yet, for Soulen 
(1996:31), 'structural supersessionism designates a problem that pervades the standard model as a whole', which would refer to the way in which salvation history is understood traditionally, involving a culmination and completion of salvation and identity in Christ.

As can be derived from Wright's exposition of the different versions of supersessionism and Soulen's different forms of supersessionism, two interrelated, preliminary conclusions about supersessionism can be drawn: First, although Wright's exposition of 'Jewish' supersessionism accentuates aspects of continuity with the faith of biblical Israel, all supersessionst approaches accentuate some form of discontinuity with Israel of the Old Testament; and second, supersessionist approaches advocate various degrees of discontinuity with biblical Israel (Wright) or they accentuate certain hermeneutical aspects of discontinuity with historical Israel (Soulen).

\section{Is replacement inherently part of the hermeneutic of the New Testament writers, especially Paul?}

Apart from scholars such as Soulen (1996:33), who argues that supersessionism is part of the way in which Christians traditionally understood the 'theological and narrative unity of the Christian canon as a whole', scholars such as Rosemary R. Ruether (1974:246-251) went even further, insisting that anti-Judaism is the left hand of Christology. In the foreword of Ruether's (1974:12-13) book, Gregory Baum argued that this 'left hand of Christology' resulted in a 'radical distinction' between church and synagogue to the point that even 'the dichotomies of salvation between spirit and flesh, light and darkness ... were projected on the opposition between Church and Synagogue'. The question remains, however, if the notion of supersession can be identified as inherent to the way in which the New Testament writers, especially Paul, portrays the gospel message. This question will mainly be pursued on the basis of the concepts of fulfilment, messianism, eschatology and newness.

The notion that Christ has fulfilled the history of salvation can be identified with several New Testament writers. The idea that Scripture has been fulfilled ( $\pi \lambda \eta \rho$ ó $\omega)$ around the ministry and person of Christ, which is most prominent in the Gospel of Matthew (Mt 1:22; 2:15, 17, 23; 4:14; 8:17; 12:17; 13:35; 21:4; $26: 54,56 ; 27: 9)$, but also occur in the other gospels (Mk 14:49; Lk 4:21; 24:44; ${ }^{3}$ Jn 12:38; 13:18; 15:25; 17:12; 18:9; 19:24; 19:36 Ac $1: 16 ; 3: 18 ; 13: 27)$, can be understood as bringing these prophesies into realisation or 'to bring [them] to a designed end' (Bauer et al. 2000 - s.v. $\pi \lambda \eta \rho o ́ \omega \$ 4)$. This means that the first Christ advent was the point of reference of these prophecies and that the prophecies were fulfilled and completed in Christ. I have argued elsewhere (Du Toit 2018b) that, in light of Jesus' discourse about the law in the whole gospel, the fulfilling ( $\pi \lambda \eta \rho{ } \omega)$ of the Law and the Prophets, according to Jesus' saying in Matthew 5:17, can be interpreted in a dialectical way, which involves a thesis, an antithesis and

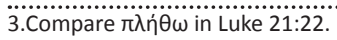

a synthesis. In such a reading, the fulfilment of the Law and the Prophets in Matthew 5:17 can be understood as 'filling up' the law to the point of impossibility, which is especially embodied by Jesus' command to be perfect as the heavenly Father is perfect (Mt 5:21-48). This forms the thesis of Jesus' discourse around the law in the gospel, which, in turn, necessitates the salvation-historical fulfilment of the Law and the Prophets by and in Christ. Part of the antithesis to the requirement to be perfect is Jesus' invitation to receive him (Mt 10:37-40), to enter into his rest, to take on his light and easy yoke (11:28-30) and even to have childlike dependence and faith in order to enter the kingdom $(18: 3 ; 19: 14)$, which all stand in contrast with the demands of the law. The fulfilment and completion of the Law and the Prophets find expression in Jesus' teaching (Mt 10:40; 17:5) and especially in his death and resurrection, wherein he serves as ransom for all sin and transgressions against the law (20:28). This salvationhistorical completion of the Law and the Prophets involves the inauguration of a new covenant (Mt 26:26-28) in which the double love command fulfils and incorporates the essential values of the law, but ultimately relieves people from adherence to its strict stipulations (22:37-40), constituting the new synthesis.

A similar idea around the concept of fulfilment is found in the undisputed Pauline letters. In Romans 8:4, Paul mentions that the right(eous) requirement $(\delta 1 \kappa \alpha i \omega \mu \alpha)$ of the law is fulfilled ( $\pi \lambda \eta \rho o \omega)$ in 'us', which include both Judaean and gentile believers who walk not according to the flesh ( $\sigma \alpha ́ \rho \xi)$, but according to the Spirit $(\pi v \varepsilon \tilde{v} \mu \alpha)$. The right(eous) requirement of the law probably points to the demand that the law should be done perfectly in order to fulfil its requirements (cf. Rm 2:13) - something that only Jesus could do and indeed accomplished on Christ-believers' behalf. Yet, this fulfilment is not separated from believers' lifestyle, which is empowered by God's Spirit as eschatological gift (Middendorf 2013:613-615; Moo 2018:505-508; cf. Hultgren 2011:300). In Romans 13:8, Paul argues that one who loves another has fulfilled $\left(\pi \lambda \eta \rho{ }^{\prime} \omega\right)^{4}$ the law and in 13:10 that love is the fulfilment $(\pi \lambda \eta \dot{\rho} \omega \mu \alpha)$ of the law. This fulfilment points to the law's culmination and eschatological fulfilment in Christ (Moo 2018:831, 834), which causes Christ-believers who love others to have 'satisfied the demands of the law en toto' (Moo 2018:831; cf. Longenecker 2016:980-981). The same idea is found in Galatians 5:14, where Paul points to the love command as the whole law being fulfilled ( $\left.\pi \lambda \eta \rho \omega^{\omega} \omega\right)$ in one 'word', which means that believers who love others fulfil all the requirements of the whole law (cf. DeSilva 2018:451) as a result of the 'eschatological completion' of the law in 'the cross as ultimate embodiment and pattern of sacrificial love' (Moo 2013:347, 348; cf. Hays 2000:322-324). In Galatians 4:4, $\pi \lambda \eta \dot{\rho} \omega \mu \alpha$ is used in connection with salvation-historical or eschatological time that has reached 'fullness'. Here, the concept of fulfilment is used in connection with the eschatological turning of ages or dispensations (DeSilva 2018:354; Hays 2000:283; cf. Keener 2019:336; Mk 1:15). 4.It is noteworthy that this verb is never used in relation to the law in the Septuagint (LXX) or any other Jewish texts (DeSilva 2018:451). 
In terms of the disputed Pauline material, a similar concept to that of Galatians 4:4 is used in Ephesians 1:10, where the unification of all things in Christ is realised as part of God's will and plan for the fullness $(\pi \lambda \eta \dot{\rho} \omega \mu \alpha)$ of (all) times. This fulfilment has been inaugurated at the first Christ advent, although future completion is awaited (Arnold 2010:88; Baugh 2016:93). ${ }^{5}$ In the Pauline literature, the notion of fulfilment, especially when it is used in relation to the law, stands for the completion of an era and the inauguration of a new era in which God's Spirit accomplishes in believers what the law intended to accomplish, but could not accomplish because of people's inability and weakness to adhere to the demands of the law (see esp. Rm 8:3-4).

In respect of messianism, as argued in more depth elsewhere (Du Toit 2015:63-67), Paul perceived Jesus as the Messiah of the historical nation Israel (Rm 1:3-4; Moo 2018:44; Schreiner 2018:43; Wright 2002:415-416; Rm 9:5; Moo 2018:585; Schreiner 2018:476; Wright 1992:307-320, 2002:629). Paul connects Jesus' Davidic messiahship (Rm 1:3) with the 'root of Jesse' (Rm 15:12), which can be considered as 'full-fledged messianic exegesis' of Isaiah 11:10 (Novenson 2009:369). In fact, even the way in which messianism developed in later Rabbinic Judaism could be considered as partly a reaction on the belief that Jesus is the Messiah (Charlesworth 1992:16, 30; Dahl 1992:382). Although messianic expectation at the time of the second temple was not uniform, the fundamental hope for Israel's liberation from oppression for the restoration of the land and the rebuilding of the temple was prominent. A central way in which this hope was expressed was the division of history into two eras: the present age and the age to come in which Israel would be restored (Wright 1992:299; cf. Weinfeld 1997:218-219). Paul's rhetoric in this regard can be understood such as that the exile was undone, God's people's sins were forgiven and the covenant has been renewed in Christ and the Spirit (Wright 1992:409; 2013:1061-1078). In this reading, historical Israel's end has come and their eschatological hope has been fulfilled in Christ, although having been redrawn and renewed (see esp. Rm 8:18-30; 1 Cor $2: 6 ; 10: 2-3,11 ; 15: 20-28 ;$ Gl 1:4; 4:3-7). It is noteworthy that when Paul discusses the promise to Abraham in Romans 4 and Galatians 3, there is neither mention of the inheritance of the land (e.g. Gn 12:7; Is 57:13) nor of Israel's national reign over the nations (e.g. Is 11:10-14) by way of a worldwide dominion (e.g. Is 9:7). Believers rather inherit the whole cosmos ( $\mathrm{Rm}$ 4:13). The Messiah's reign is thus now of a different kind (Wright 2013:911, 1065). According to Paul's understanding of messiahship, the hope of Israel has been fulfilled in another way than anticipated: God's rule in Christ is not a political or territorial rule, but spiritual (Fitzmyer 2007:183; Witherington 1992:57) and cosmic (Rm 14:9; 15:12; Phlp 2:9-11) in which God's people enjoy heavenly citizenship (Phlp 3:20) and cosmic inheritance (Rm 4:13). God's people are now the new temple (1 Cor 3:16-17; $6: 19 ; 2$ Cor 6:16) and the Messiah's body in this world (Rm 12:5; 1 Cor 12:27). God's kingdom is a fulfilled reality in believers' lives, although it contains a component of future completion (Rm 14:7; 1 Cor 4:20; 1 Th 2:12; cf. Wright 2013:1073-1074).

In the Pauline corpus, the eschatological implication of the new age or dispensation is conveyed on several levels. Apart from the way in which messianic fulfilment is portrayed, the eschatological realisation of the new era in Christ is explicitly mentioned in 1 Corinthians 10:11, where Paul writes that 'the end/culmination of the ages has come/arrived' ( $\tau \grave{\alpha} \tau \varepsilon \dot{\varepsilon} \lambda \eta \tau \tilde{\tau} v$

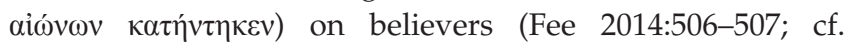
Gardner 2018:437).

Although the new epoch stands in continuity with the old, there exists a 'contrast between the age of Israel and the age of the church' (Thiselton 2000:745). Yet, on a deeper level,

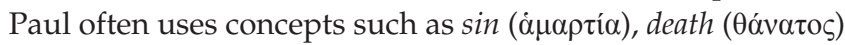
and law (vó $\mu \mathrm{s})$ in combination as supra-individual realities or spheres of power that belong to the previous age before the revelation of Christ ( $\operatorname{Rm} 3: 9 ; 5: 12,17,21 ; 6: 9 ; 7: 14,17,20 ; 1$ Cor 15:21, 26, 56; see esp. Ridderbos 1975:93, 100, 125-126, 208). These concepts stand in contrast with the principle (vó $\mathrm{o}_{\text {) }}$ of the Spirit of life in Christ that has set people free from the principle (vó $\left.\mathrm{o}_{\mathrm{S}}\right)$ of sin and death $(\operatorname{Rm} 8: 2) .{ }^{6}$ Likewise, in the eschatological resurrection body, the sting of death has been removed (1 Cor 15:55). Similarly, at the end of Romans 7, Paul cries: 'who will deliver me from this body of death'

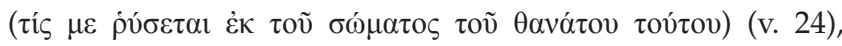
which seems to metaphorically refer to 'this sum total' of death or 'of human sin and depravity' (Longenecker 2016:669, 670). In respect of the law, Paul portrays the existence in the previous age as an existence 'under [the] law' (Rm 2:12; 3:19; 6:14, 15; 1 Cor 9:20; Gl 3:23; 4:4, 5, 21; 5:18; Phlp 3:6). Yet, in 1 Corinthians 9:20, Paul specifically states that he is not 'under

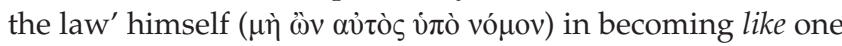
under the law in order to win those under the law. There has thus been a fundamental change of position or alignment to the law, sin and death in Paul's existence in the new era in Christ. In the new identity in Christ, there has thus been a change of masters: Christ-believers are not under the lordship of law, sin and death, but under the lordship of Christ, under grace and under the guidance of the Spirit (cf. Rm 6:14-17).

Pointedly, in Romans 7:5-6, after portraying the law as something that believers in Christ have died to, just as a woman whose husband died and who is not subjected to the law of marriage any more ( $\mathrm{Rm} 7)$, Paul argues that:

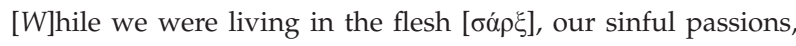
aroused by the law, were at work in our members to bear fruit for death. But now [vvví] we are released from the law, having died to that which held us captive, so that we serve in the new

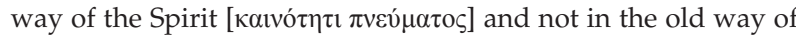

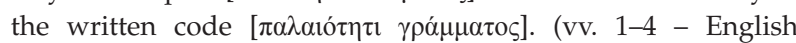
Standard Version [ESV])

Two eras, two ways of existence or two identities are contrasted here (see esp. Fee 1994:510-511; Moo 2018:439-448;

6. It is the majority view among commentators that vónos here points to a principle in both instances rather than to the Mosaic law (e.g. Longenecker 2016:685; Moo 2018:497; Schreiner 2018:396). 
Ridderbos 1959:145; Thielman 2018:339). In these two verses, vvví ('now') carries eschatological significance in that it divides two epochs in salvation history (Jewett 2007:437; Longenecker 2016:637). In the first epoch, people were under (the power of) law, sin and death, and people's identity was marked off by the works of the law. In the new epoch in Christ, people are 'now' subjected to the reign of the Spirit and not to the old way of the written code. In these two verses, $\sigma \alpha ́ \rho \xi$ and $\pi v \varepsilon \tilde{u} \mu \alpha$ are used in such a way that both carry eschatological connotations in that $\sigma \alpha \dot{\rho} \rho \xi$ signifies a way of existence in the era before or outside of Christ and $\pi v \varepsilon \tilde{v} \mu \alpha$ signifies a way of existence in the new era in Christ (Du Toit 2019a:189-192). The same connotations to $\sigma \alpha ́ \rho \xi$ and $\pi v \varepsilon \tilde{v} \mu \alpha$ can be identified in Romans 8:1-16 (Du Toit 2019a:199-206) ${ }^{7}$ and Galatians 5:16-25 (Du Toit 2019a:206-212). ${ }^{8}$

As argued more extensively elsewhere (Du Toit 2019b:6-17), Paul often uses vĩv [now] in an eschatological way to indicate

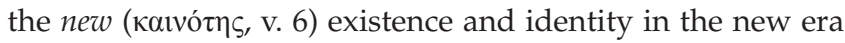
in Christ in contrast to the old existence and identity in the old era before or outside of Christ. Pertinent instances where this is the case, is Paul's famous sayings in Galatians 2:19-20 that he died to the law so that he might live to God; he has been crucified with Christ; it is no longer Paul himself (' $\mathrm{I}$ ') who lives, but Christ who lives in him; the life that he 'now' (võv) lives, he lives by faith in the Son of God. The võv indicates a new, eschatological (Silva 2001:175) way of existence and a new identity apart from the existence under the law. Similarly, in Romans 3:21, a major turning point in Paul's argument occurs when he states that righteousness has 'now' (vvví) been manifested apart from the law, where vvví indicates the salvation-historical contrast between the old era and identity under the law, and the new era and identity in Christ (cf. võv or vvví in Rm 5:9-11; 16:25-26; 2 Cor 6:2; Eph 2:13; 5:8; Col 1:22). Paul can also picture faith as something that has come (Gl 3:25), signifying a new dispensation wherein a believer stands in a new relationship to God.

The new eschatological existence that results from the Christ-event is also evident in the Letter to the Hebrews, which starts off eschatologically by stating that in 'these last

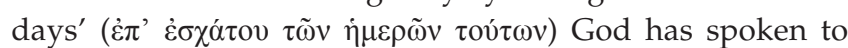
believers by his Son, in contrast to speaking to the fathers by the prophets 'at many times' ( $\pi$ o $\lambda v \mu \varepsilon \rho \tilde{\omega} \varsigma)$ and in many ways before (Heb 1:1-2). Against this eschatological background, according to Hebrews 8:6, Christ has 'now' (vvví) $)^{9}$ obtained a ministry that is much more excellent than the old, as the covenant that Christ mediates is better, based

\footnotetext{
7.The absoluteness or mutual exclusiveness of the respective existences in oáp $\pi v \varepsilon \tilde{u} \mu \alpha$ is especially evident in the disclaimer in Romans 8:9: 'You, however, are not in the flesh but in the Spirit.' In other words, it is a condition that is not applicable to believers. The same verse states the counter-reality: 'Anyone who does not have the Spirit of Christ does not belong to him [Christ]', which implies that if one does not have the Spirit, such a person is in a flesh-existence.

8. In this passage, the absolute nature of the respective existences in $\sigma \alpha \dot{\rho} \rho \xi$ and $\pi v \varepsilon \tilde{u} \mu \alpha$ can especially be derived from the way in which Paul pictures the existence under the leadership of $\pi v \varepsilon \tilde{u} \mu \alpha$ as not being under the law (GI $5: 18)$, from the end of the leadership of $\pi v \varepsilon \tilde{u} \mu \alpha$ as not being under the law (GI 5:18), from the end of
those who do the works of $\sigma \alpha \dot{p} \rho \xi$ as not inheriting God's kingdom (GI 5:21) and from

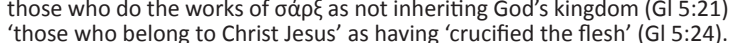

9.This reading occurs in $\mathfrak{P}^{46 c} N A D^{1} K L P \Psi$ 0278. 33. 81. 104. 365. 630. 1175. 1241 1505. 1739. 1881. $2464 \mathfrak{M}$. Yet, the reading vũv is testified by $\mathfrak{P} 46^{*} B D^{*}$
}

on better promises. But apart from indicating a contrast to the earthly priesthood according to the law (Heb 8:4), the vvví also carries temporal, eschatological significance (Ellingworth 1993:408-409; Koester 2001:378; O'Brien 2010:291-292). ${ }^{10}$ Although this new covenant fulfils the prophecy to 'the house of Israel and the house of Judah' (Heb 8:8, quoting Jr 38:31 - LXX), and thus stands in continuity with the old covenant, the new covenant brings an eschatological end to the old (cf. Heb 8:13).

In sum, the idea that an eschatologically new era or epoch by the promised Messiah fulfils and completes the previous era or epoch under law, sin and death, inevitably involves a replacement of sorts. That does not mean that the replacement of the pervious epoch by the new one constitutes a kind of 'sweeping' replacement, where everything else prior to the eschatological inauguration has been swept aside by the new revelation (see the second point in Wright's exposition above), but it does indicate that the new dispensation, which stands in continuity with the old epoch, ultimately transcends and replaces the old (see esp. Fee 1994:813-814).

A logical result of eschatological fulfilment is that the eschatological epoch that replaces the previous one is indeed new. The idea of newness is probably the strongest indicator of replacement with the writers of the New Testament. Again, the newness is not an invasion from nowhere, but constitutes the ultimate result of prophetic and eschatological fulfilment. In this regard, the concept of a new creation

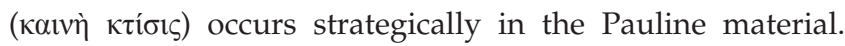
In 2 Corinthians 5:17, Paul writes about the 'new creation' that came into being for someone that is 'in Christ'. Both an individual and corporate, eschatological dimension are present here. In other words, the believer acquires a new identity in Christ, which is part of a 'new created order' (Guthrie 2015:308) or a 'new eschatological situation that has emerged from Christ's advent' (Martin 2014:312; cf. Du Toit 2019a:156-164). Such a notion is confirmed by the subsequent references to the work of Christ in reconciling 'us' to himself, giving 'us' the ministry of reconciliation, and the reference to the reconciliation of the 'world to himself' (2 Cor 5:18-19). ${ }^{11}$ In Galatians 6:14-15, Paul states that, by the cross of Christ, the world has been crucified to Paul and Paul to the world. As a result, neither circumcision nor uncircumcision counts for anything, 'but a new creation'. Silva (2001:184) strongly argues for the eschatological basis of the new creation: Paul criticises his opponents for not recognising the 'eschatological significance' of the cross and for seeking to remain in the 'old world of circumcision'. In contrast, those who belong to the new creation are 'no longer alive to the old age', but 'live according to a different pattern of existence', constituting 'the true, eschatological people of God'. Likewise, Fung (1988:307) maintains that Galatians 6:14 goes beyond a subjective experience and signifies 'two objectively existent worlds, from one of which he [Paul] has been transplanted to another'. 10.Compare the use of vũv in 1 Peter 1:12; $2: 10 ; 3: 21$.

11.Seifrid (2014:252) argues that the 'breaking eschaton' is localised in that only Christ-believers take part in the new creation. 
The underlying thought is 'that the cross - standing for the Christ-event as a whole - marks the end of the old world and users in the new' (cf. Dunn 1993:342-343; Hays 2000:344-345; Keener 2019:574-575; Moo 2013:398; Vos 1930:49). The new creation thus eschatologically fulfils and replaces the previous order. Similarly, in Romans 6:4, the burial with Christ, signified by baptism, results in walking 'in newness of life', just as Christ was raised from the dead. Likewise, 1 Corinthians 11:25 refers to the Lord's Supper as representing 'the new covenant' (cf. Lk 22:20) in Jesus' blood. There is thus an eschatological aspect to the Lord's Supper (Gardner 2018:512-513), which signifies the new relationship wherein believers stand with God on the basis of Christ's blood. The idea of a new covenant in 1 Corinthians 11:25 recalls Jeremiah 38:31-34 (LXX) in which the new covenant stands in continuity with the old, but ultimately replaces the old reality (Lundbom 2008:466).

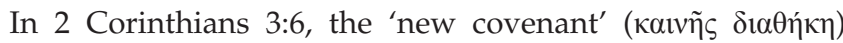
forms part of the main theme of this chapter and indicates 'the eschatological new order' (Martin 2014:195). According to Seifrid (2014:122), 'the very naming of this covenant as "new" means that it is defined in contrast with the "old" and that ' $[t]$ he former commandment thus is displaced by the fulfilled promise' (cf. Guthrie 2015:198; Harris 2005:271). At heart, the new covenant in the Spirit both fulfils and replaces the previous, obsolete epoch and way of existence (Fee 1994:307-308; cf. Wright 2013:980-984).

In tandem with the eschatological overtones in the Letter to the Hebrews (see above), the notion of a 'new covenant'

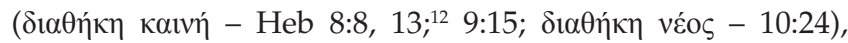
which is contrasted with the 'first' ( $\pi \rho \tilde{\omega} \tau o \varsigma$ - Heb 8:13), 'obsolete' ( $\pi \alpha \lambda \alpha$ ió $\omega$ - Heb 8:13) covenant, is a prominent theme in the letter. Life in the 'new covenant' is also conveyed

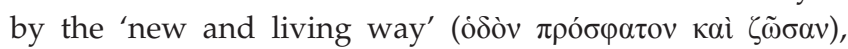
which is established through the opening of the veil to the holiest by Jesus' body (Heb 10:20). Although the new covenant is explained from an angle that is different from that in the Pauline corpus, it ultimately points to the same new reality for believers. As with Paul, the element of newness in Hebrews signifies more than eschatological fulfilment, but ultimately points to a new covenant that replaces the old (Koester 2001:388; Michaels 2009:392; O'Brien 2010:302-303; Thompson 2008:170, 176).

In respect of the disputed Pauline material, the concept of newness is especially conveyed by the idea of a 'new self/

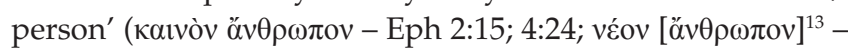
Col 3:10), which signifies the new identity (Arnold 2010:289-290) and the new existence (Baugh 2016:375) of the person living in the new eschatological age inaugurated by the Christ-event. In respect of Ephesians 2:15, which states that 'one new person in place of the two' (ESV) is created in Christ, Arnold (2010:162) remarks that the work of Christ

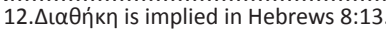

13.'AvӨ $\rho \omega \pi$ rov is not strictly part of Colossians 3:10, but is implied from the previous verse, which has 'old self/person' ( $\pi \alpha \lambda \alpha$ เòv äv $\theta \rho \omega \pi \mathrm{ov})$. marked the end of the Mosaic covenant' and that 'the era of the law has come to an end'. More precisely, 'the law in its entirety has been abolished insofar as it functions as the basis of the covenant relationship between God and his people'. Regarding the new identity, Arnold continues that 'Christ's purpose went beyond creating a climate where Jews and Gentiles could get along. He exerted his divine creative power to form an entirely new class of humanity' (cf. Hoehner 2002:379). This new identity inevitably replaces the old identities, which were separated by the dividing wall

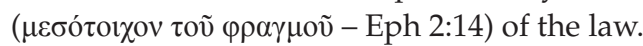

In respect of the Synoptic Gospels, apart from the notion of a 'new testament/covenant' that is signified by Jesus' blood (Lk 22:20), the idea of 'new wine' in fresh wineskins (Mt 9:17; Mk 2:22; Lk 5:37-38) points to the 'unsuitability of the old covenant as a vessel for the new covenant' (Osborne 2010:343). The new wine signifies 'the new age' that Jesus inaugurates, which goes hand in hand with new practices in accordance with changed circumstances (Blomberg 1992:159; cf. Edwards 2015:171-172; Schnabel 2017:76).

In the Johannine writings, the notion of a 'new commandment' (Jn 13:34; 1 Jn 7, 8; 2 Jn 1:5) could be seen as John's equivalent of the new covenant (Lk 22:20; 1 Cor 11:25; Michaels 2010:758; cf. Carson 1991:484). The command is not new in the sense that it has not been said before ( $\operatorname{Lv} 19: 18)$, but it is new in that it is bound up with the new standard of Jesus' love for his disciples (Jn 13:34) and, in that, it both mandates and exemplifies 'the new order', which goes along with 'the newly gathering messianic community, brought into existence by the redemption long purposed by God himself (Carson 1991:484-485).

Lastly, the idea in both the Old and the New Testaments of an awaited new heaven and earth (Is 65:17; 66:22; 2 Pt 3:13; Rv 21:1) and the idea that a New Jerusalem would descend from heaven ( $\operatorname{Rv} 3: 12 ; 21: 2)$, imply a replacement of the old created order by a new created order. The notion of replacement is conveyed by the statement in Isaiah 65:17 that 'the former things shall not be remembered or come into mind' (ESV) (e.g. Smith 2009:718), the prediction in 2 Peter $3: 12$ that 'the heavens will be set on fire and dissolved, and the heavenly bodies will melt as they burn' (ESV) (e.g. Bauckham 2002:324, 334) and especially the words in Revelation 21:1 that 'the first heaven and the first earth had passed away, and the sea was no more' (ESV) (e.g. Osborne 2002:729). In view of the latter text, one is hard pressed to maintain a view that the new heaven and earth are merely a recreation of the former (contra Moo 1996:204-205). In fact, if the 'new' is merely a refurbishment of the old, it is not really new. The saying in Revelation 21:5, 'I am making all things new', thus has to be interpreted in view of 21:1 as conveying a completely new creation. Although the new heaven and earth point to a future reality, it can be understood as the completion of the new creation, which has already been inaugurated at the Christ-event (cf. Beale 1999:1052; Osborne 2002:737). 
In sum, when the notions about fulfilment, the messiahship of Christ, realised eschatology and newness in the New Testament are considered, they paint a picture of a new order that was inaugurated in Christ, which fulfilled, transformed and ultimately replaced the old order. The old existence under the bondage of the powers of law, sin and death has been replaced by a new existence under grace and under the lordship of Christ and the guidance of the Spirit. The new covenant has both fulfilled and replaced the old covenant. The dawn of the new eschatological epoch thus does not invade the world from nowhere, but constitutes the fulfilment and the ultimate end or goal of the old.

\section{What exactly is replaced according to Paul?}

If the notion of replacement is inherently and inevitably part of the gospel, the question still remains: What exactly is it in the eschatologically old existence under the law that is replaced in the new eschatological existence in the Spirit or in the new covenant? Part of this question is the following: What are the essential characteristics of the new existence in the new order in contrast with the old order?

I have argued elsewhere that Paul in Galatians 3 fundamentally redefines the criteria of covenant membership and identity (Du Toit 2018a). Identity is not marked off by the 'works of the law' $(\mathrm{Gl} 3: 2,5,10)$ any more, which includes circumcision (Gl 5:2-3, 6, 11; 6:12, 13, 15), the abstention from eating unclean food (Gl 2:11-14) and the keeping of certain days, months, seasons and years (Gl 4:10). Yet, the 'works of the law', to which those in the old epoch before or outside of Christ are subjected to, requires that the law should be done perfectly in order to live (Gl 3:10, 12), which implies that people in the old epoch are under the curse of the law (G1 3:10, 13). In the new epoch, however, people partake in the promise(s) to Abraham (G13:16-19, 21-22, 29) and become Abraham's 'sons' (G1 3:7) or God's 'sons' (Gl 3:26) through faith (Gl 3:6-9, 22, 24) and by partaking of the Spirit (Gl 3:3, 14). Faith is thus portrayed as something that 'came' ( $\dot{\varepsilon} \lambda \theta \varepsilon \tilde{\varepsilon} v-$

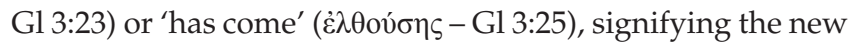
condition for covenant membership in the new era. A righteous position before God (Gl 3:21) now begins with the

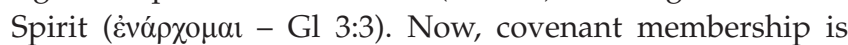
not signified by being the (biological or physical) 'seed' of Abraham any more, but by belonging to Christ (Gl 3:29), which is the true 'seed' of Abraham (Gl 3:16). The criteria for covenant membership and even the claim to God's promise (Gl 3:29) in the new epoch are thus now irrespective of ethnicity or people group (G1 3:28), and is now dependent on belonging to Christ only (Gl 3:29). The identification with Christ is signified by baptism in which the candidate 'clothes' him- or herself ${ }^{14}$ with Christ (G1 3:27), which in turn, points to the acquiring of a new identity (see esp. Du Toit 2013a). Similar principles apply in Romans 3, where Paul declares that the righteousness of God is 'now' revealed apart from

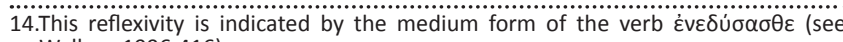
Wallace 1996:416). the law. Righteous is now through faith ( $\operatorname{Rm~3:21-22,26).~A~}$ new 'law' or principle (Longenecker 2016:445; Moo 2018:269; Schreiner 2018:210) is now operative - the 'principle of faith' (vó $\mu$ ov $\pi \dot{i} \sigma \tau \varepsilon \omega \varsigma$ ) - which means that someone is justified by faith apart from the deeds of the law ( $R m$ 3:27-28).

At heart, the essential characteristic of the new covenant is that identity is not marked off by external, 'fleshly' markers of identity or identity markers that are in the sphere of human possibility (e.g. works of the law, circumcision, biological or physical descent, the observance of days, the abstention from certain foods), but by internal, 'spiritual' markers of identity (faith and the Spirit), which are in the sphere of divine possibility. The flesh-Spirit dichotomy also relates to the latter contrast. In other words, that which is replaced in the new epoch, is not the racial or ethnic composition of God's people, but the criteria for covenant membership and identity, which is inclusive of all people irrespective of race, biological descent or ethnicity.

Paas (2018:28), however, refers to replacement theology 'as if God's promise of saving grace after the advent of Christ is not meant for the Jewish people any more', which goes against the above mentioned principle. He (Paas 2018) also writes that:

Jews should be happy that God does not maintain their special Old Testament covenant position but has effected and absorbed it in Jesus Christ through whose work He has made it applicable to all peoples. (p. 34)

Paas (2018:36) thus advocates the idea of the continuation of Israel (p. 36), which he understands as a widening of Israel to all nations (pp. 21, 22, 28). In the same volume, Colin Chapman (2018:117) distantiates himself from 'Replacement Theology and Supersessionism' by referring to Munther Isaac (2015:261) who argues that gentile believers do not replace Israel, but 'are incorporated into Israel'. Likewise, Martin Van Veelen (2018:268) argues in the same volume that 'the Church that has been gathered by the Apostles (Ac 2:1) is not the replacement of Israel but the legal continuation of Israel' [emphasis original]. It seems that all of these researchers who react against replacement theology, react against a kind of 'hard' supersessionism (see Wright's first point above) - a kind of supersession that is not generally argued in scholarship. But, as Wright (2013:809-810) points out, the view that Israel is now redefined to include the church, is also a form of replacement theology (see Wright's third point above). This is indeed a form of replacement, in that the criteria of covenant membership and identity in the new epoch in Christ were replaced by a new set of criteria. The church is thus now composed by a new set of people, that replaces the composition of God's people in the Old Testament. A new identity and way of relating to God, replaces the old identity and way of existence. The anti-replacement rhetoric that exists in the above mentioned versions of the 'redefined/new Israel' view thus constitutes a kind of oxymoron: it argues against a largely theoretical version of replacement in order to substitute it with another version of replacement. 
Although I (Du Toit 2019a:334-345) have argued that Israel has reached its culmination and end in Christ, and that, despite Galatians 6:16, ${ }^{15}$ the people of God in the new epoch are not to be understood as a redefined or new 'Israel' as such; the idea of replacement lies even deeper than Wright's third, 'softer' version of replacement theology. In fact, in view of the new criteria for identity in the new epoch, the idea that Israel is continued in the new epoch in which gentile believers are (merely) added, seems to deconstruct itself. For one thing, in the 'redefined Israel' (Robertson 2018:231; cf. Isaac 2015:250; Wright 2013:914-925, 1432-1433), 'renewed Israel' (Wright 2013:408, 1416) or 'new Israel' view (Beale 2018:78, 85; Chapman 2018:118; Paas 2018:16), historical Israel could not have continued as a nation, for the criteria of biological descent or ethnicity has been discarded in the new identity. In the 'redefined/new Israel' view, the criteria for identity have indeed been replaced by a new set of criteria. The idea that a redefined Israel would avert antisemitism is not evident, for ethnic or biological descendants of historical Israel are not included in the redefined Israel by default. In the 'redefined/new Israel' view, physical or ethnic Israelites are indeed replaced by a spiritual 'Israel'. Although covenant membership in the old epoch involved more than being part of national Israel and also included a spiritual dimension (e.g. Rm 9:6-8; see e.g. Beale 2018:61), national Israel was also part of God's broader covenant people. In fact, the eight privileges of historical Israel listed in Romans 9:4-5 (adoption, glory, covenants, legislation, service, promises, the fathers, Christ according to the flesh) can all be understood as privileges in which national Israel shared by default. Sharing in these privileges thus did not necessarily imply salvation (Moo 2018:583; Osborne 2004:238). ${ }^{16}$ Even according to the 'redefined/new Israel' view, national Israelites in New Testament times also had to come to belief in Christ in order to be included in the redefined Israel; otherwise they would be left out. In the 'redefined/new Israel' view, the continuation with historical Israel is thus essentially in theory and not actual.

\section{What hermeneutic principles distinguishes replacement and anti-replacement approaches?}

In anti-replacement views such as the Radical New Perspective on Paul (RNPP), also called the 'Paul within Judaism' view, Paul is regarded as still being fully Torah observant, including the keeping of circumcision, the

\footnotetext{
15.I have argued that the kai [and] in the phrase and upon the Israel of God in Galatians 6:16 is a normal copulative kai, which conveys a contrast with the new people in the new era in Christ (those 'who walk by this rule' of the new creation). In context of the contrast between the new and old salvation-historical epochs in the whole letter and the tendency in the time of the second temple to use the term Israel to refer to historical Israel (esp. Josephus), the 'Israel of God' probably points to God's people in the old covenant. In Galatians 6:16, Paul would thus be blessing God's people in the new epoch (those walking according to the new rule) as well as in the old epoch (God's historical Israel). Because Paul does not address the destiny of ancient, historical Israel as such in the letter such a last measure of balance can be interpreted as an attempt to fill this gap, although in a very cursory manner.

16. For example, 'adoption' (vio $\theta \varepsilon \sigma i \alpha$ ) in Romans 9:4 has to mean something different from Romans $8: 15,23$, where adoption results from the receiving of the Spirit in the now $1.15,23,1$ here the new era in Christ (Moo 2018.582-583). Similarly, in Galatians 4.5, adoption is preceded by the sending of God's Son and the redemption of those under the law, which implies that such adoption was inaugurated at the Christ-event.
}

observance of certain days and the adherence to food laws. In this approach, Paul's letters are understood as being addressed to gentile believers only, which are accommodated within the covenant under the condition that they do not adhere to all the commandments of the law such as circumcision, the observance of certain days or food laws. They would be subject to a limited set of requirements as set out in the so-called Apostolic Decree (Ac 15:19-20), which proponents of this view identify with the so-called Noahide or Noachic laws. In terms of ecclesiology, they would thus see the church as an entity consisting of both 'Jewish' and gentile believers - each with their own set of conditions for covenant membership and each retaining their distinctive ethnic identities (e.g. Campbell 2008:89-93; Eisenbaum 2009:252; Nanos 2012:123-124; Rudolph 2011).

Yet, there is a way in which even in the 'redefined/new Israel' view, an ethnic kind of hermeneutic prevails. As seen from the literature, an important intent of seeing the church as a redefined or new Israel is to avert the possible allegation of antisemitism and even of replacement theology. But apart from the fact that the notion of replacement can indeed be identified within the 'redefined/new Israel' view (see above), there seems to be a measure of correspondence with the RNPP in that many proponents of the 'redefined/new Israel' view would argue that historical Israel continues in a way in the church, with gentile believers being included into Israel (e.g. Chapman 2018:116; Robertson 2018:231; Van Meggelen 2018:158), as if ethnic differentiation continues in some way within a multi-ethnic church or as if there exists at least a measure of continuation between ethnic Israel of the Old Testament and the church.

In terms of the redefined criteria of identity and covenant membership in the new epoch in Christ, however, ethnicity becomes totally irrelevant in marking off identity. Granted, all ethnicities are included in Christ on the same level, but none of these ethnic identities are, in any way, constitutive of marking off identity in the new covenant any longer (Gl 3:28). Ironically, in anti-replacement approaches, which include a rhetoric against replacement in some of the 'redefined/new Israel' approaches (e.g. Beale 2018; Chapman 2018; Paas 2018), ethnicity either remains an important constitutive factor in identity (RNPP) or pervades beneath the surface within their hermeneutical approach ('redefined/ new Israel' approaches that include an anti-replacement rhetoric), even if it only exists in the notion to call the church 'Israel' in order to avert antisemitism. At heart, the essential hermeneutical difference between replacement theology and anti-replacement theology is that, in anti-replacement approaches, ethnicity remains constitutive of its hermeneutic in some way, whereas in a full replacement approach, it is not the case.

In respect of other hermeneutical differences, as discussed already, replacement and anti-replacement approaches work with different sets of criteria for identity. In the RNPP, for example, 'flesh' inevitably remains a part of their hermeneutic 
in that ethnic differences are perceived to remain constitutive of the church. It can be argued that things such as law observance and circumcision also remain in the domain of 'flesh' (e.g. Boyarin 1994:84-85). Yet, a more fundamental hermeneutical difference can be identified in the way in which the relationship between the Old and the New Testament is understood. In anti-replacement approaches, a tendency exists not to differentiate (too sharply) between the Old and New Testament. In other words, the in-Christ identity almost stays within the sphere of historical Israel's faith and religious identity. The tendency is to merely expand Israel with added conditions to include gentile Christbelievers, where salvation history is not seen as inaugurating a fundamentally new covenant, a new identity or an existence that supersedes the old existence. In the fulfilmentreplacement approach, however, the Christ-event is understood as filling up, fulfilling, culminating and ending the old epoch under the law (constituting continuity), which inevitably leads to a new covenant, a new identity and a new existence that transcends and supersedes the old existence (constituting discontinuity). The latter hermeneutical difference converges with a different hermeneutic in respect of eschatology. In anti-replacement approaches, eschatology seems to be moved forward in that the Christ-event is not seen as a full inbreaking of the new eschatological epoch. In a replacement approach, however, the Christ-event is understood as an innately eschatological event in which messianic hope is fulfilled, the eschatological Spirit is given to believers as a first fruit of the eschaton ( $\mathrm{Rm} \mathrm{8:23)}$ and believers, although living between the times, already share in a new, eschatological existence, which will be fully completed in the future.

A last but important hermeneutical difference between antireplacement and replacement approaches is the perceived relationship of contemporary Jews and Judaism with Israel of the Bible. As pointed out before, contemporary Jews and Judaism cannot be equated with Israel of the Old Testament at least not in a linear way. As scholars such as Neusner (1984:1-5), Langer (2003:258) and Mason (2007:502) pointed out: Rabbinic Judaism, as we know it today, is strictly a development after $70 \mathrm{CE}$, which, as pointed out above, was in some ways a reaction against Christianity. To equate today's Jews with the 'Iovoaior of the New Testament (in linear way), would thus be anachronistic. ${ }^{17}$ Within much of recent anti-replacement rhetoric as well as rhetoric against antisemitism, however, there exists a hermeneutical tendency

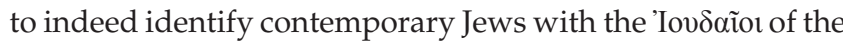
New Testament and even with the Israel of the Old Testament. ${ }^{18}$ But more importantly, in the full replacement view, the terminus ad quem of ethnic Israel as the covenant people is the Christ-event itself.

17.This is also the reason why the idea of the Noahide laws, being an operative hermeneutic in New Testament times, is untenable for it is essentially part of later Rabbinic Judaism that postdates New Testament times (Du Toit 2013b).

18.This is apart from the fact that in the time of the second temple, there existed a

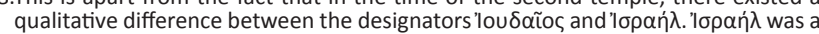
term mostly used as an insider term to point to historical Israel of the Old

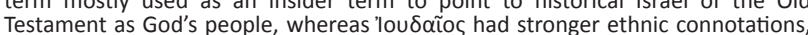
was more of an outsider term, and did not necessarily include the connotation of was more of an outsider term, and did not necessarily include
being God's people (see esp. Josephus; Du Toit 2019a:31-39).

\section{Conclusion: Is replacement theology anti-Semitic?}

As pointed out in this article, replacement theology is not a uniform phenomenon. There are 'harder' and 'softer' versions of replacement theology. Yet, I have argued that the idea of replacement is innately part of the hermeneutic of the authors of the New Testament. The element of replacement is especially present in the way in which the criteria for identity and covenant membership in the eschatologically new epoch is defined. This replacement, however, is rooted and flows forth from the Old Testament itself, in that it constitutes the ultimate outcome of the fulfilment and culmination of the history of salvation. It is thus not a kind of 'sweeping' replacement, wherein everything in the old epoch is discarded or not regarded as meaningful. Neither is replacement in the New Testament a kind of 'hard' replacement, wherein gentiles replaces Israel as God's people-a position that is hardly argued in recent scholarship, but nevertheless became a kind of red herring against which many anti-replacement proponents, including some who advance the view that the church is the 'renewed/new Israel', continue to argue. I have also argued that, as Wright (2013) admits, the 'renewed/new Israel' view involves the same essential replacement of criteria for identity and covenant membership, which makes the rhetoric against replacement within proponents of the 'renewed/new Israel' view ironic.

Is replacement theology anti-Semitic? As argued, in a hermeneutic where the criteria of identity and covenant membership are solely constituted by faith and the indwelling Spirit, race, biological descent or ethnicity are not in any way constitutive of identity or covenant membership any more. The contention that fulfilment-replacement theology is anti-Semitic, however, still operates within a fleshly hermeneutic where race, biological descent or ethnicity somehow still forms part of the hermeneutic in respect of the in-Christ identity. To answer the question, replacement theology that follows from fulfilment cannot be anti-Semitic, for neither race, biological descent nor ethnicity is part of its hermeneutic. Biblical replacement theology does not favour any nation above another or advocates the replacement or displacement of historical Israel by gentiles. Apart from this, the idea that replacement theology is antiSemitic, involves a hermeneutic where contemporary Jews are anachronistically equated with Israel of the Old Testament (in a linear way). The assertion that replacement theology is anti-Semitic, arguably does not embrace the full replacement in which race, biological descent or ethnicity is not constitutive of its hermeneutic of identity. In other words, the notion that full replacement theology is antiSemitic is essentially a category mistake in that it forces replacement theology through a fleshly or ethnic hermeneutic - a hermeneutic that is not inherent to replacement theology as such. 


\section{Acknowledgement Competing interest}

The author declares that he have no financial or personal relationships which may have inappropriately influenced him in presenting this article.

\section{Ethical consideration}

This article followed all ethical standards for a research without direct contact with human or animal subjects.

\section{Funding information}

This research received no specific grant from any funding agency in the public, commercial, or not-for-profit sectors.

\section{Data availability statement}

Data sharing is not applicable to this article as no new data were created or analysed in this study.

\section{Disclaimer}

The views and opinions in this article are those of the author and do not necessarily reflect the official policy or position of any affiliated agency of the author.

\section{References}

Arnold, C.E., 2010, Ephesians (Zondervan Exegetical Commentary on the New Testament). Zondervan, Grand Rapids, MI.

Bartkowski, J.P., 2007, 'Anti-Semitism (religion)', in G. Ritzer (ed.), The Blackwell encyclopedia of sociology, pp. 152-154, Blackwell, Malden, MA.

Bauckham, R.J., 2002, 2 Peter, Jude (Word Biblical Commentary), Word, Dallas, TX.

Bauer, W., Danker, F.W., Arndt, W.F. \& Gingrich, F.W. (eds.), 2000, A Greek-English Lexicon of the New Testament and other early Christian Literature, University of Chicago Press, Chicago, It.

Baugh, S.M., 2016, Ephesians, Lexham, Bellingham, WA. (Evangelical Exegetical Commentary).

Beale, G.K., 1999, The book of revelation (The New International Greek Testamen Commentary), Eerdmans, Grand Rapids, MI.

Beale, G.K., 2018, 'Israel's land in relation to the new covenant', in S. Paas (ed.), Israelism and the Place of Christ: Christocentric interpretation of biblical prophecy, pp. 60-87, LIT Verlag, Berlin.

Beller, S., 2007, Antisemitism: A very short introduction, Oxford University Press, Oxford.

Blomberg, C., 1992, Matthew (The New American Commentary), B\&H, Nashville, TN.

Boyarin, D., 1994, A radical Jew: Paul and the politics of identity, University of California Press, Berkeley, CA.

Byford, J., 2006, 'Distinguishing "Anti-Judaism" from "Antisemitism": Recent championing of Serbian bishop Nikolaj Velimirović', Religion, State and Society 34(1), 7-31. https://doi.org/10.1080/09637490500459867

Campbell, W.S., 2008, Paul and the creation of Christian identity, T\&T Clark, London.

Carrol, J., 2002, Constantine's sword: The church and the Jews, Houghton Mifflin, Boston, MA.

Carson, D.A., 1991, The Gospel according to John (The Pillar New Testament Commentary), Eerdmans, Grand Rapids, MI.

Chapman, C., 2018, 'Christian interpretation of Ezekiel's prophecies', in S. Paas (ed.), Israelism and the Place of Christ: Christocentric interpretation of biblical prophecy, pp. 88-121, LIT Verlag, Berlin.

Charlesworth, J.H., 1992, 'From messianology to Christology: Problems and prospects' in J.H. Charlesworth (ed.), The Messiah: Developments in earliest Judaism and Christianity, pp. 3-35, Fortress, Minneapolis, MN.

Dahl, N.A., 1992, Messianic ideas and the crucifixion of Jesus', in J.H. Charlesworth (ed.), The Messiah: developments in earliest Judaism and Christianity, pp. 382-403, Fortress, Minneapolis, MN.

DeSilva, D.A., 2018, The letter to the Galatians (The New International Commentary on the New Testament), Eerdmans, Grand Rapids, MI.
Donaldson, T.L., 2009, 'Supersessionism in early Christianity', Canadian Society of Biblical Studies Bulletin 69, 1-27.

Du Toit, P.L.G., 2013a, 'The "clothe" metaphor in Paul and the entity taking the active role in baptism', Nederduits Gereformeerde Teologiese Tydskrif 54(1-2), 29-39. https://doi.org/10.5952/54-1-2-303

Du Toit, P.L.G., 2013b, 'Perspektiewe op die Noagitiese Wette by Paulus, en die Belang daarvan vir Joods-Christelike Dialoog', Litnet Akademies 10(1), 631-656.

Du Toit, P.L.G., 2015, 'The hermeneutical dilemma behind "anti-Judaism" in the New Testament: An evangelical perspective', Conspectus 20(10), 43-88.

Du Toit, P.L.G., 2018a, 'Galatians 3 and the redefinition of the criteria for covenant membership in the new faith-era in Christ', Neotestamentica 52(1), 41-67. https://doi.org/10.1353/neo.2018.0002

Du Toit, P.L.G., 2018b, 'The fulfilment of the law according to Matthew 5:17: A dialectical approach', Acta Theologica 38(2), 46-69. https://doi.org/10.18820/ 23099089/actat.v38i2.4

Dunn, J.D.G., 1993, A commentary on the epistle to the Galatians, A\&C Black, London. (Black's New Testament Commentaries).

Du Toit, P.L.G., 2019a, God's saved Israel: Reading Romans 11:26 and Galatians 6:16 in terms of the new identity in Christ and the spirit, Pickwick, Eugene, OR.

Du Toit, P.L.G., 2019b, 'Was Paul a Christian?', Neotetamentica 53(1), 1-29. https:// doi.org/10.1353/neo.2019.0007

Edwards, J.R., 2015, The Gospel of Luke (The Pillar New Testament Commentary), Eerdmans, Grand Rapids, MI.

Eisenbaum, P., 2009, Paul was not a Christian: The original message of a misunderstood apostle, HarperCollins, New York.

Ellingworth, P., 1993, The Epistle to the Hebrews (The New International Greek Testament Commentary), Eerdmans, Grand Rapids, MI.

Fee, G.D., 1994, God's empowering presence: The Holy Spirit in the letters of Paul, Baker Academic, Grand Rapids, MI.

Fee, G.D., 2014, The first epistle to the Corinthians (The New International Commentary on the New Testament), rev. edn., Eerdmans, Grand Rapids, MI.

Fitzmyer, J.A., 2007, The one who is to come, Eerdmans, Grand Rapids, MI.

Fung, R.Y.K., 1988, The epistle to the Galatians (The New International Commentary on the New Testament), Eerdmans, Grand Rapids, MI.

Gager, J.G., 1983, The origins of anti-semitism: Attitudes toward Judaism in Pagan and Christian antiquity, Oxford University Press, Oxford.

Gager, J.G., 2000, Reinventing Paul, Oxford University Press, Oxford.

Gardner, P., 2018, 1 Corinthians, Zondervan, Grand Rapids, MI. (Zondervan Exegetical Commentary on the New Testament).

Guthrie, G.H., 2015, 2 Corinthians, Baker Academic, Grand Rapids, MI. (Baker Exegetical Commentary on the New Testament).

Harris, M.J., 2005, The second epistle to the Corinthians (The New International Greek Testament Commentary), Eerdmans, Grand Rapids, MI.

Hays, R.B., 2000 'The letter to the Galatians', in L.E. Keck (ed.), The new interpreter's Bible, vol. 11, pp. 181-348, Abingdon, Nashville, TN.

Hoehner, H.W., 2002, Ephesians: An exegetical commentary, Baker Academic, Grand Rapids, MI.

Hoet, H., 2001, "'Abraham is our father" (John 8:39): The Gospel of John and JewishChristian dialogue', in R.D. Bieringer, D. Pollefeyt \& F. Vandekasteele-Vanneuville (eds.), Anti-Judaism and the fourth Gospel: Papers of the Leuven Colloquium, 2000, pp. 187-201, Royal Van Gorcum, Assen.

Hultgren, A.J., 2011, Paul's letter to the Romans: A commentary, Eerdmans, Grand Rapids, MI.

Isaac, M., 2015, From land to lands, from Eden to the renewed earth: A Christ-centered biblical theology of the promised land, Langman Monographs, Carlisle.

Jewett, R., 2007, Romans (Hermeneia), Fortress, Minneapolis, MN.

Käsemann, E., 1980, Commentary on Romans, transl. G.W. Bromiley, SCM, London. Keener, C.S., 2019, Galatians: A commentary, Baker Academic, Grand Rapids, MI.

Koester, C.R., 2001, Hebrews (The Anchor Yale Bible), Yale University Press, New Haven, CT.

Langer, R., 2003, 'Jewish understandings of the religious other', Theological Studies 64(2), 255-277. https://doi.org/10.1177/004056390306400202

Langmuir, G.I., 1971, 'Anti-Judaism as the necessary preparation for anti-semitism', Viator: Medieval and Renaissance Studies 2(1), 383-389. https://doi.org/ Viator: Medieval and Renais

Langmuir, G.I., 1990, Toward a definition of antisemitism, University of California Press, Berkeley, CA.

Lemert, C., 2006, 'Ethnicity and ethnic groups', in B.S. Turner (ed.), The Cambridge dictionary of sociology, pp. 174-175, Cambridge University Press, Cambridge.

Levenson, J.D., 1993, The death and resurrection of the beloved son: The transformation of child sacrifice in Judaism and Christianity, Yale University Press, New Haven, CT.

Longenecker, R.N., 2016, The epistle to the Romans (The New International Greek Testament Commentary), Eerdmans, Grand Rapids, MI.

Lundbom, J.R., 2008, Jeremiah 21-36, (The Anchor Yale Bible), Yale University Press, New Haven, CT.

Martin, R.P., 2014, 2 Corinthians (Word Biblical Commentary), 2nd edn., Zondervan, Grand Rapids, Ml.

Martyn, J.L., 1997, Galatians (The Anchor Bible), Doubleday, New York, NY. 
Mason, S., 2007, 'Jews, Judaeans, Judaizing, Judaism: Problems of categorization in ancient history', Journal for the Study of Judaism 38(4-5), 457-512. https://doi. org/10.1163/156851507X193108

Mason, S. \& Esler, P.F., 2017, 'Judaean and Christ-follower identities: Grounds for a distinction', NTS 63(4), 493-515. https://doi.org/10.1017/S0028688517000145

Michaels, J.R., 2009, 'Commentary on Hebrews', in P.W. Comfort (ed.), Cornerstone biblical commentary, vol. 17, pp. 303-478, Tyndale House, Carol Stream, IL.

Michaels, J.R., 2010, The Gospel of John (The New International Commentary on the New Testament), Eerdmans, Grand Rapids, MI.

Middendorf, M.P., 2013, Romans 1-8 (Concordia Commentary), Concordia, Saint Louis, MO.

Moo, D.J., 1996, 2 Peter, Jude (The NIV Application Commentary), Zondervan, Grand Rapids, MI.

Moo, D.J., 2013, Galatians (Baker Exegetical Commentary on the New Testament), Baker Academic, Grand Rapids, M

Moo, D.J., 2018, The letter to the Romans, rev. edn., Eerdmans, Grand Rapids, MI. (The New International Commentary on the New Testament).

Murrell, N.S., 1994, 'The human Paul of the New Testament: Anti-Judaism in 1 Thess 2:14-16', Proceedings 14, 169-186.

Nanos, M.D., 2012, 'Paul's relationship to Torah in light of his strategy "to become everything to everyone" (1 Corinthians 9.19-23)', in R. Bieringer \& D. Pollefeyt
(eds.), Paul and Judaism: Crosscurrents in Pauline exegesis and the study of (eds.), Paul and Judaism: Crosscurrents in Pauline exegesis
Jewish-Christian relations, pp. 106-140, T\&T Clark, London.

Neusner, J., 1984, Messiah in context: Israel's history and destiny in formative Judaism, Fortress Press, Philadelphia, PA.

Nichols, W., 1993, Christian antisemitism: A history of hate, Rowman \& Littlefield, Lanham, MD.

Novenson, M.V., 2009, 'The Jewish Messiahs, the Pauline Christ, and the gentile question', Journal of Biblical Literature 128(2), 357-373. https://doi. org $/ 10.2307 / 25610187$

O'Brien, P.T., 2010, The letter to the Hebrews, Eerdmans, Grand Rapids, MI. (The Pillar New Testament Commentary).

Osborne, G.R., 2002, Revelation (Baker Exegetical Commentary on the New Testament), Baker Academic, Grand Rapids, MI.

Osborne, G.R., 2004, Romans (The IVP New Testament Commentary Series), IVP Academic, Downers Grove, IL.

Osborne, G.R., 2010, Matthew (Zondervan Exegetical Commentary on the New Testament), Zondervan, Grand Rapids MI.

Paas, S. (ed.), 2018, Israelism and the place of Christ: Christocentric interpretation of Biblical prophecy, LIT Verlag, Berlin.

Ridderbos, H., 1959, Aan de Romeinen, Kok, Kampen. (Commentaar op het Nieuwe Testament).

Ridderbos, H., 1975, Paul: An outline of his theology, transl. J.R. de Witt, Eerdmans, Grand Rapids, MI.

Robertson, O.P., 2018, 'The Israel of God in Romans 11', in S. Paas (ed.), Israelism and the Place of Christ: Christocentric interpretation of biblical prophecy, pp. 212-232, LIT Verlag, Berlin.
Rudolph, D.J., 2011, A Jew to the Jews: Jewish contours of Pauline flexibility in 1 Corinthians 9:19-23, Mohr Siebeck, Tübingen.

Ruether, R.R., 1974, Faith and fratricide: The theological roots of anti-semitism, Seabury, New York.

Schnabel, E.J., 2017, Mark (Tyndale New Testament Commentaries), IVP Academic, Downers Grove, IL.

Schreiner, T.R., 2018, Romans (Baker Exegetical Commentary on the New Testament), 2nd edn., Baker Academic, Grand Rapids, MI.

Seifrid, M.A., 2014, The second letter to the Corinthians (The Pillar New Testament Commentary), Eerdmans, Grand Rapids, MI.

Silva, M., 2001, Interpreting Galatians: Explorations in exegetical method, 2nd edn., Baker Academic, Grand Rapids, MI.

Slater, T.B., 2012, Ephesians (Smyth \& Helwys Bible Commentary), Smyth \& Helwys, Macon, GA.

Smith, G., 2009, Isaiah 40-66 (New American Commentary), B\&H, Nashville, TN.

Soulen, R.K., 1996, The God of Israel and Christian theology, Fortress, Minneapolis, MN.

Soulen, R.K., 2013, 'The standard canonical narrative and the problem', in D. Rudolph \& J. Willits (eds.), Introduction to messianic Judaism: Its ecclesial context and biblical foundations, pp. 282-291, Zondervan, Grand Rapids, MI.

Stone, J. \& Piya, B., 2007, 'Ethnic groups', in G. Ritzer (ed.), The Blackwell encyclopedia of sociology, pp. 1457-1459, Blackwell, Malden, MA.

Thielman, F., 2018, Romans (Zondervan Exegetical Commentary on the New Testament), Zondervan, Grand Rapids, MI.

Thiselton, A.C., 2000, The first epistle to the Corinthians (The New International Greek Testament Commentary), Eerdmans, Grand Rapids, MI.

Thompson, J.W., 2008, Hebrews (Paideia Commentaries on the New Testament), Baker Academic, Grand Rapids, MI.

Van Meggelen, J., 2018, 'The restoration of Israel's Kingdom', in S. Paas (ed.), Israelism and the Place of Christ: Christocentric interpretation of biblical prophecy, pp. 147-159, LIT Verlag, Berlin.

Van Veelen, M., 2018, 'Who are the Goyim?', in S. Paas (ed.), Israelism and the Place of Christ: Christocentric interpretation of biblical prophecy, pp. 262-270, LIT Verlag, Berlin.

Vos, G., 1930, The Pauline eschatology, Eerdmans, Grand Rapids, MI.

Wallace, D.B., 1996, Greek grammar beyond the basics: An exegetical syntax of the New Testament. Zondervan, Grand Rapids, MI.

Weinfeld, M., 1997, 'Expectations of the Divine Kingdom in biblical and postbiblical literature', in H.G. Reventlow (ed.), Eschatology in the bible and in Jewish and Christian tradition, pp. 218-232, Sheffield Academic, Sheffield.

Witherington, B., III, 1992, Jesus, Paul and the end of the world: A comparative study in New Testament eschatology, IVP, Downers Grove, IL.

Wright, N.T., 1992, The New Testament and the people of God, SPCK, London.

Wright, N.T., 2002, 'The letter to the Romans', in L.E. Keck (ed.), The new interpreter's Bible, vol. 10, pp. 394-770, Abingdon, Nashville, TN.

Wright, N.T., 2013, Paul and the faithfulness of God, 2 vols., SPCK, London. 